\title{
Development of Finnish Elementary Pupils' Problem- Solving Skills in Mathematics
}

Anu Laine ${ }^{\star 1}$, Liisa Näveri ${ }^{2}$, Maija Ahtek 3 And Erkki Pehkonen ${ }^{4}$

$\approx$ The purpose of this study is to determine how Finnish pupils' problemsolving skills develop from the 3 rd to 5 th grade. As research data, we use one non-standard problem from pre- and post-test material from a three-year follow-up study, in the area of Helsinki, Finland. The problems in both tests consisted of four questions related to each other. The purpose of the formulation of the problem was to help the pupils to find how many solutions for a certain answer exist. The participants in the study were 348 third-graders and 356 fifth-graders. Pupils' fluency, i.e. ability to develop different solutions, was found to correlate with their ability to solve the problem. However, the proportions of the pupils ( $17 \%$ of the 3 rd graders and $21 \%$ of the 5 th graders) who answered that there were an infinite number of solutions are of the same magnitude. Thus, the pupils' ability to solve this kind of problem does not seem to have developed from the 3 rd to the 5 th grade. The lack and insufficiency of pupils' justifications reveal the importance of the teacher carefully listening to the pupils' ideas in order to be able to promote pupils' understanding of the concept of infinity, as well as the basic calculations.

Keywords: open problem, development of problem-solving skills, infinity, Finnish elementary school, mathematics 


\section{Razvoj spretnosti reševanja matematičnih problemov pri finskih osnovnošolcih}

Anu Laine*, Liisa Näveri, Maija Ahtee in Erkki Pehkonen

$\approx$ Namen prispevka je ugotoviti, kako se med finskimi osnovnošolci razvijajo spretnosti reševanja problemov od tretjega do petega razreda. Podatki študije so bili zbrani na podlagi enega nestandardnega problema iz pred- in potesta v okviru triletne t. i. sledilne študije na območju Helsinkov na Finskem. Problema obeh testov sta bila sestavljena iz štirih med seboj povezanih vprašanj. Oblikovana ali pripravljena sta bila tako, da sta bila učencem $v$ pomoč pri iskanju števila mogočih rešitev na posamezen odgovor. Vključenih je bilo 348 tretješolcev in 356 petošolcev. Fluentnost učencev, tj. sposobnost razvijanja različnih rešitev, je bila povezana z njihovo sposobnostjo, da so problem rešili. Vendar pa je delež učencev ( $17 \%$ tretješolcev in $21 \%$ petošolcev), ki so odgovorili, da je mogočih rešitev neskončno, ostal enak. Zdi se torej, da se sposobnost učencev za reševanje tovrstnih problemov od tretjega do petega razreda ni razvila. Pomanjkanje in nepopolnosti v utemeljitvah učencev kažejo, kako pomembno je, da učitelj pozorno posluša ideje učencev, da bi nato lahko spodbujal njihovo razumevanje koncepta neskončnosti in osnovnih izračunov.

Ključne besede: odprti problem, razvijanje spretnosti reševanja problemov, neskončnost, finska osnovna šola, matematika 


\section{Introduction}

Already at the elementary level in Finland, the aim of learning mathematics is also to understand mathematical structures, not merely to learn mechanical calculations. The curriculum for the Finnish comprehensive school (NBE, 2004) has problem solving as one of the formal objectives for all school subjects. Pupils should be able to make justified conclusions, explain their actions and present their solutions via concrete models, treatments, voice and written texts (NBE, 2004). Current thinking among researchers and reformers is that mathematical discourse involving explanation, argumentation, and that the defence of mathematical ideas should be a defining feature of a quality classroom experience (Walshaw \& Anthony, 2008). Pedagogical practices that create opportunities for students to explain their thinking and to engage fully in dialogue have been reported by Steinberg, Empson, and Carpenter (2004). By expressing their ideas, students are able to make their mathematical reasoning visible and open for reflection.

This paper considers pupils' skills in solving a non-standard task, an open problem, and the development of pupils' skills from $3^{\text {rd }}$ to $5^{\text {th }}$ grade.

\section{Problem solving}

It may be said that the base for research on modern problem solving was created in the 1950 s by George Polya, when he introduced his four-step model for problem solving: 1) Understanding the problem, 2) Devising a plan, 3) Carrying out the plan and 4) Looking back (cf. Polya, 1945). Nowadays, problem solving is understood and usually offered as a method to develop mathematical thinking (e.g. Schoenfeld, 1985).

In this paper, we will apply a rather widely used characterisation for a problem (cf. Kantowski, 1980): a task is said to be a problem if the solving if it requires the solver to connect the task to his/her earlier knowledge in a (for him/her) new way. If he/she can immediately recognise the procedure needed for solving the task, it is a routine task (or a standard task or exercise) for him/ her. The concept of 'problem' is thus relative in terms of time and of the person concerned. Simple addition tasks, such as $3+4$, could be problems for a school beginner, whereas after some years they are routine tasks.

When the teacher offers a problem task to the pupils, it might be familiar (similar ones have been solved before) to some of them, and thus it is no longer a problem to them. The so-called non-standard tasks differ markedly from those typically presented in mathematics textbooks. Non-standard tasks are often 
surprising and unusual, and demand new kinds of thinking from solvers. For example, most of the PISA tasks are non-standard problems (cf. OECD, 2006).

Mathematical tasks can also be divided into open and closed tasks (cf. Boaler, 1998). In a closed task, both the starting and end points are uniquely determined. The solver needs only to find the route to the solution. Most of the tasks in mathematics textbooks are closed, whereas in open tasks there are several alternatives for the starting and/or end situations, as well as for the solution method.

In the 1970s, a new method for mathematics teaching, the so-called open approach (cf. Becker \& Shimada, 1997; Nohda, 2000) was developed in Japan. In an open-ended problem, the starting point is given, but the end is open. Therefore, open problems have many possible answers. One example of an open-ended task is as follows: 'Divide a rectangle into three triangles. Can you find another solution? How many solutions are there altogether?'

\section{Creativity}

Creativity can be described as performance by which an individual produces something new and unpredictable (cf. Silver, 1997). There are two principal definitions of mathematical creativity: the creation of new knowledge and flexible problem-solving abilities (Kwon, Park, \& Park, 2006). Creative people are able to produce new ideas even from poorly-defined information using the principles of intuition. Intuition is defined as cognitions that appear subjectively to be self-evident, immediate, certain, global, coercive (Fischbein, 1999). Intuition can be thought as unconscious thinking in which the connection and the logic of the steps cannot be seen (cf. Ericsson, 2003). In the literature of mathematics education, the term 'creative problem solving' (CPS) is used to a certain extent to emphasise the aspect of creativity in problem solving (cf. Pehkonen, 2004). CPS offers a powerful set of tools for productive thinking: these can be learned and used successfully (Treffinger, 1995). The purpose is primarily to change formal thinking habits and attitudes to more flexible and receptive ones.

Divergent thinking is the ability to draw on ideas from across disciplines and fields of inquiry in order to reach deeper understanding (Guilford, 1956). Often, it is based on imagination, hopping illogically from one topic to another, mainly without connections, whereas convergent thinking generally means the ability to give the 'correct' answer to standard questions. Thus, it is logical, striving purposefully to the set goal (Guilford, 1956). It is often said that in mathematics, and also in problem solving, two types of thinking modes are needed: divergent thinking that is used to generate creative ideas, and convergent 
thinking in which logic is in the focus, i.e. creative thinking (divergent), for which intuition is typical and analytical thinking (convergent) where logic is in the focus. Studies exist that systematically attempt to improve pupils' divergent thinking (e.g. Kwon et al., 2006).

There are four components of creativity in the Torrance Tests of Creative Thinking (cf. Torrance, 1974): fluency (i.e. how fluent the solver is in creating a large number of ideas or alternative solutions), flexibility (i.e. how flexible the solver is in seeing things from different points of view and using many different strategies during the process of solving the problem), originality (i.e. how capable the solver is to produce unique and unusual ideas or put together old ideas in a new way), and elaboration (i.e. how capable the solver is to process ideas by providing more details that deepen the understanding of the topic). In Japan, when using the teaching method of the open approach, teachers aim to develop pupils' problem-solving skills and creativity. In creativity, the focus is in the three first components of creativity (Shimada, 1997).

\section{Potential infinity}

Infinity is a fundamental concept in mathematics; it is encountered as early as in counting when children understand that there is no endpoint. Such ongoing processes without an end are usually the first examples of infinity for children; such processes are called 'potential infinity'.

Infinity awakens curiosity in children even before they enter school (e.g. Wheeler, 1987). In the elementary curriculum, infinity is implicitly present in many of the topics, e.g. in arithmetic when dealing with fractions, or when introducing straight lines in geometry. Some of these ideas (e.g. straight line) are introduced to the pupils as early as in the $2^{\text {nd }}$ grade (NBE, 2004). Therefore, pupils in the $3^{\text {rd }}$ and $5^{\text {th }}$ grades are familiar with the idea of potential infinity, although what infinity means is not covered during the elementary school. Consequently, infinity remains mysterious for most students throughout their school years (e.g. Pehkonen \& Hannula, 2006). For example, even 16-18 yearold English students' primary focus on infinity is as a process, i.e. something which goes on and on (Monaghan, 2001).

\section{The purpose of this study}

This paper is based on the information gathered in the comparative study between Finland and Chile in 2010-2013, a research project (Project \#1135556) that is partly funded by the Academy of Finland. In the background study of the project, pupils' mathematical skills were measured with a test in the beginning 
of the third grade in autumn 2010 and at the end of the fifth grade in spring 2013, with the same pupils. Since the Chilean school year begins six months later than in Finland, we do not yet have all the Chilean results; consequently, we are not able to make any comparison between the countries. Therefore, we will here restrict ourselves in the comparison of the Finnish results in the $3^{\text {rd }}$ and $5^{\text {th }}$ grades. In this study, there have been 10 experimental and 10 control classes.

The purpose of this article is to analyse the development of Finnish pupils' problem-solving skills from the $3^{\text {rd }}$ to the $5^{\text {th }}$ grade. The research problems are stated as follows:

- How do the pupils solve a non-standard problem at the $3^{\text {rd }}$ and at the $5^{\text {th }}$ grade?

- How fluent are the pupils in inventing answers?

- How do the pupils explain the number of solutions when the difference or respectively the quotient of two numbers is two?

- What kind of understanding do the third and the fifth graders have of infinity?

\section{Method}

\section{Participants and data collection}

The data in this article consist of mathematics tests that were carried out in the autumn of 2010, at the beginning of the $3^{\text {rd }}$ grade and in spring 2013 , at the end of the $5^{\text {th }}$ grade, as a part of the comparative project's background measurements. In autumn 2010, the pupils $(\mathrm{N}=348)$ were about nine years old. Ten classrooms were selected for experimental and ten classrooms for control groups in the Helsinki metropolitan area. In spring 2013, the same school classes were tested again $(\mathrm{N}=356)$. All the pupils who were at school on testing days took the test; therefore, there is the different number of pupils in the first and second tests. Furthermore, some pupils had changed their classrooms or schools.

Both tests were constructed so that they measured different parts of pupils' knowledge of mathematics (calculation, application and problem-solving skills) and each part had some anchor tasks in order to find out the development in this area. For each test, the pupils were allowed 45 minutes. In this study, we analyse one problem from both tests.

The task is a so-called guiding exercise in which questions are presented one after another. In third grade, the task was to produce certain subtractions, and in fifth grade divisions. In addition, pupils were asked to ponder how many of this type subtraction /division task there are altogether. The aim of the 
guiding exercise was to help pupils to picture the number of calculations.

The task was formulated as follows in the $3^{\text {rd }}$ grade:

1. Find numbers with the difference of 2. For example

- $5-3=2$

- ${ }_{-}^{-}+{ }_{-}$

- $-{ }_{-}=2$

2. Can you find more examples? What kind? Give the examples.

3. How many subtractions with a difference of 2 do you think there are altogether?

4. Why?

In the $5^{\text {th }}$ grade, the task was identical, except of the calculation 'Find numbers with the quotient of 2 .'

\section{Data analysis}

Pupils' answers were coded depending on the complexity of the answer to three categories: correct, wrong and no answer. The statistical analysis containing frequencies, means, dispersions and Pearson's correlations was made with the SPSS program package. The reliability was tested by t-test with significance levels of $0.05,0.01$ and 0.001 . In the calculations of the differences of percentages in the $3^{\text {rd }}$ and $5^{\text {th }}$ grade results, we use the common agreement for the levels of statistical risks. The significance of the difference between percentages was tested using Z-test.

Pupils' verbal justifications for the number of subtractions or quotients were analysed more closely. The analysis was qualitative, and it can be characterised as inductive content analysis (Patton, 2002). The written responses were interpreted and categorised by comparing the similarities and differences in the pupils' answers. All answers were recorded in a database so that all the researchers could make their own suggestions separately. After some trials, a crude division to three categories (justification correct, justification wrong, no justification) was decided.

\section{Results}

First, we will present results from the $3^{\text {rd }}$ grade, then from the $5^{\text {th }}$ grade, and finally look at the development of both pupils' problem-solving skills and their idea of the number of subtractions/quotients from the $3^{\text {rd }}$ to the $5^{\text {th }}$ grade. 


\section{Situation at the $3^{\text {rd }}$ grade}

Most of the pupils (93\%) found two correct subtractions in the first part of the task (see Table 1). The wrong answers were mostly of the type that the pupils had made subtractions with an answer of -2, i.e. they had not understood the meaning of the order of the numbers in the calculation. In the next part, the pupils had to invent more examples. They invented from o to 14 new solutions. About one third of the pupils wrote down also subtractions that contained numbers with two or more digits. Six pupils invented a subtraction task that was coded as original. Most of these contained large numbers, e.g. 1,000,00o$999,998=2$. One pupil used even decimal numbers (10,000.5-9,998.5). Flexibility and elaboration, the other components of creativity, are not relevant here because of the form of the task.

Table 1. Third graders' findings for subtractions

\begin{tabular}{|c|c|c|}
\hline & Answers $(\mathrm{N}=348)$ & $\begin{array}{l}\text { The proportion of } \\
\text { the answers (\%) }\end{array}$ \\
\hline \multirow{4}{*}{$\begin{array}{l}\text { Find numbers with the difference } \\
\text { of } 2 \text {. For example } \\
5-3=2 \\
-_{-}^{-}=2 \\
-_{-}^{-}=2\end{array}$} & Both correct & 93 \\
\hline & One correct & 5 \\
\hline & Both wrong & 2 \\
\hline & No answer & 0 \\
\hline \multirow{4}{*}{$\begin{array}{l}\text { Can you find more examples? } \\
\text { What kind? }\end{array}$} & $\begin{array}{l}\text { Examples with 2- or more-digit } \\
\text { numbers* }\end{array}$ & 47 \\
\hline & Examples with 1-digit numbers* & 33 \\
\hline & Wrong solutions & 5 \\
\hline & No answer & 15 \\
\hline
\end{tabular}

*Pupils' examples from the first part of the task were also taken into account in these percentages if a pupil had not invented more examples.

We were also interested in the pupils' fluency, i.e. the number of invented solutions in the second part of the task. The aim of the first part of this guiding task was that the pupils while inventing examples would also realise that there can be an infinite number of solutions. In Table 2, we present the distribution of pupils' solutions. Most of the pupils gave from three to five examples. 
Table 2. Third graders' fluency in inventing subtractions with a difference of 2

\begin{tabular}{lcccc}
\hline The number of solutions & 0 & $1-2$ & $3-5$ & $\geq 6$ \\
\hline The number of pupils & 58 & 96 & 114 & 80 \\
\hline
\end{tabular}

In the third part of the task, the pupils were asked to ponder how many subtraction tasks for the difference of 2 there are altogether (see Table 3). The number of correct subtractions was divided into three parts: infinite, more than 20 (this varied up to numbers with even 12 zeroes after one) and less than 20. The pupils were able to write about 20 subtractions on the answer sheet. After that, they had to imagine the subtractions in their head. When a pupil did not answer the question, but instead gave more examples his/her response was coded as 'wrong answer'. Only $17 \%$ of the pupils gave an answer that there is an infinite amount of subtractions giving the difference 2 .

Table 3. Third graders' answers to the question about the number of the subtraction tasks with the difference of 2

\begin{tabular}{llc}
\hline & Answers (N= 348) & $\begin{array}{c}\text { The proportion of the } \\
\text { answers (\%) }\end{array}$ \\
\hline \multirow{3}{*}{$\begin{array}{l}\text { How many subtractions with } \\
\text { the difference of 2 are there } \\
\text { altogether? }\end{array}$} & Infinite & 17 \\
\cline { 2 - 3 } & More than 20 & 31 \\
\cline { 2 - 3 } & Between 1 and 20 & 11 \\
\cline { 2 - 3 } & Wrong answer & 14 \\
\hline \multirow{3}{*}{ Why? } & No answer & 27 \\
\hline & Justification correct & 14 \\
\cline { 2 - 3 } & Justification wrong & 35 \\
\cline { 2 - 3 } & No justification & 51 \\
\hline
\end{tabular}

Pupils were also asked to justify their answer. About a tenth of the pupils were able to give some kind of explanation as to why there are an infinite number of subtractions (see Table 3). About half of the third graders had written down at least something as an answer to the question about why they thought there are so and so many subtractions in the fourth part of the task. The pupils' correct verbal reasons to the question what is the number of possibilities to obtain 2 as a difference between two numbers were either of the type 'No end of numbers', or of the type 'You can always subtract', whereas the incorrect justifications were more or less inexplicable. However, in each justification, category 
the pupils' answers to the preceding question (How many subtractions with the difference of 2 are there altogether?) varied from two to infinity.

More than half of the third graders, who had written something as an answer, gave an inexplicable explanation, which means that they wrote down something that did not truly explain anything. Some typical answers:

- $\quad$ Because there are many.

- $\quad$ Because there are so many calculations where the difference is two.

- Because there are different calculations in the world.

In the category 'No end of numbers', most of the pupils used the terms 'infinitely' or 'endlessly' for the number of possibilities, and their reasons were simply as follows:

- $\quad$ Because numbers will never end

- $\quad$ Because numbers will increase all the time

However, some pupils gave the same reasoning even though they gave the number of solutions as 'millions' or as 'lots of zeroes after one' or just as 'much'.

In the category 'You can always subtract', most of the pupils had written that there could be an infinite number in the third part of the task.

- $\quad$ Because you can always take off so much that 2 remains.

- When you subtract from any number something you get two.

- Because you can always subtract a number that is two less than the num-

ber from which you subtract.

Furthermore, in this category, many pupils gave more or less the same reasons even though they did not use infinity in their answer. A pupil who had given '100' as the number of possible subtractions wrote:

- Because from every other number you can calculate a difference of two, except from numbers 2 and 1.

- $\quad$ Another pupil who had given '10,000' as the number of possible subtractions wrote:

- $\quad$ Because the first number in the calculation changes with one forward and so also the other number.

- $\quad$ Or a pupil, who thought that there are a million possibilities, wrote:

- Because always if you take off from some number another number which is smaller by two the answer is two.

- $\quad$ Some of the pupils explained by giving an example:

- $\quad$ Because you can calculate e.g. $1000-998$. 
- $\quad$ Because there are many calculations like 1,000,000,004-1,000,000,002 $=2$.

- $\quad$ Because $10-8=2,100-98=2,1000-998=2,10000-9998=2$.

- $\quad$ Because if you subtract e.g. 98 from a hundred you get the number 2.

In the first example, the pupil had stated that there is an infinitely of differences, in the second 'thousand million millions', in the next hundred thousand, and in the last one a hundred.

It seems that there were at least three ways for pupils to find the justification for the number of calculations with the difference of two: 1) They had systematically written down the differences with small numbers, e.g. 2-0, 3-1, 4-2 or $9-7,10-8,11-9$; or 2 ) They had used slightly larger numbers like 50-48, 60$58,90-88$; or 3 ) Very often, they gave the difference $1000-998$ as an example.

The relation of the fluency (see Table 2) to other variables was studied because it seemed to be relevant based on the qualitative data. The fluency correlated with the size of the numbers used in the calculations $(\mathrm{r}=0.57, \mathrm{~N}=$ $348, \mathrm{p}=0.000$ ), i.e. if a pupil gave examples of subtractions with two or more digit numbers, they were more fluent. The fluency correlated also both with the conception about the amount of the numbers $(\mathrm{r}=0.32, \mathrm{~N}=348, \mathrm{p}=0.000)$ and with the justification $(\mathrm{r}=0.25, \mathrm{~N}=348, \mathrm{p}=0.000)$. In fact, the fluency correlated with all other parts of the task except the first $(r=0.05, N=348, p$ $=0.345$ ) because almost everybody had solved the problem. It seems that if a pupil had started to invent many examples to the subtraction, s/he was able to come closer to the idea of the infinity of numbers.

\section{Situation at the $5^{\text {th }}$ grade}

Most of the pupils (88\%) found two correct divisions to the first task (see Table 4). The wrong answers were mostly of the type that the pupils had divided the smaller number with the bigger one (cf. Huhtala \& Laine, 2004). In the next task, pupils had to invent more examples. They invented from o to12 new solutions; $64 \%$ of the pupils also wrote down divisions that contained numbers with two or more digits. Only eight pupils invented a division that was coded as original. These divisions contained large numbers, e.g. $10000 \div 5000$. 
Table 4. Fifth graders' findings for the division task

\begin{tabular}{|c|c|c|}
\hline & Answers $(\mathrm{N}=356)$ & $\begin{array}{l}\text { The proportion of } \\
\text { the answers (\%) }\end{array}$ \\
\hline \multirow{4}{*}{$\begin{array}{l}\text { Find the numbers with the } \\
\text { quotient of } 2 \text {. For example } \\
6 \div 3=\underline{2} \\
{ }_{-} \div- \\
{ }_{-} \div- \\
-\end{array}$} & Both correct & 88 \\
\hline & One correct & 5 \\
\hline & Both wrong & 3 \\
\hline & No answer & 4 \\
\hline \multirow{4}{*}{$\begin{array}{l}\text { Can you find more } \\
\text { examples? } \\
\text { What kind? }\end{array}$} & Examples with 2- or more-digit numbers* & 64 \\
\hline & Examples with 1-digit numbers* & 23 \\
\hline & Wrong solutions & 0 \\
\hline & No answer & 13 \\
\hline
\end{tabular}

*Pupils' examples from the first part of the task were also taken into account in these percentages if a pupil had not invented more examples.

We were also interested in the fluency, i.e. the number of invented solutions in the second part of the task. In Table 5, we present the distribution of pupils' solutions. The mode of the answers is placed in zero solutions, i.e. about one third of the pupils did not give any examples in this part of the task.

Table 5. Fifth graders' fluency in inventing divisions

\begin{tabular}{lcccc}
\hline The number of solutions & 0 & $1-2$ & $3-5$ & $6-12$ \\
\hline The number of pupils & 111 & 80 & 83 & 82 \\
\hline
\end{tabular}

Pupils were asked to ponder how many division tasks with a quotient of 2 there are altogether (see Table 6). Only one fifth of the pupils responded that there is an infinite number of divisions of that kind. 
Table 6. Fifth graders' answers to the question about the number of the division tasks with the quotient of 2

\begin{tabular}{llc}
\hline & Answers $(\mathbf{N}=356)$ & \multicolumn{1}{c}{$\begin{array}{c}\text { The proportion of the } \\
\text { answers (\%) }\end{array}$} \\
\hline \multirow{3}{*}{$\begin{array}{l}\text { How many divisions whose quo- } \\
\text { tient is 2 there are altogether? }\end{array}$} & Infinite & 21 \\
\cline { 2 - 3 } & Numbers over 20 & 38 \\
\cline { 2 - 3 } & Numbers between 1 and 20 & 19 \\
\cline { 2 - 3 } & No answer & 3 \\
\hline \multirow{3}{*}{ Why? } & Justification correct & 19 \\
\cline { 2 - 3 } & Justification wrong & 21 \\
\cline { 2 - 3 } & No justification & 43 \\
\hline
\end{tabular}

Pupils were also asked to justify their answer. About one fifth of the pupils gave a correct justification, i.e. were able to explain why there are an infinite number of division tasks (see Table 6). In the fourth part of the task, about 60\% of the fifth graders had written an answer to the question asking why this was so. The pupils' justifications for the number of possibilities to obtain 2 from a division of two numbers were divided into the three categories as earlier in the case of the third grade: 'Inexplicable explanations', 'No end of numbers', and 'Correct explanations'. It must be noted that in the fifth grade the number of possibilities also varied from a few ones to infinity.

Less than half of the fifth graders who gave an explanation gave one that did not truly explain anything. Some pupils gave the same kind of answers as the third graders:

- $\quad$ Because there are many and you can invent more.

- $\quad$ Because there are so many multiplication calculations.

However, many of these respondents paid attention to the number 2, e.g.:

- $\quad$ The result of many divisions is 2.

- $\quad$ Because 2 is an even number.

- $\quad$ Because there are so many numbers that you can multiply by two.

Some of the fifth graders spoke about multiplication table and mostly about the multiplication table of two. However, the number of possibilities was then extremely low.

- I counted them using multiplication tables. 
- $\quad$ All in the multiplication table of 2.

The majority of the fifth-graders classified in the category 'No end of numbers' stated that there are infinite or endless of possibilities to obtain 2 as a quotient, and their reasons were mostly the same as in the third grade:

- Because there are numbers endlessly.

There were also some answers in which the pupils ended with an infinite number of solutions by adding zeroes.

- $\quad$ You can always add zeroes, e.g. $4 \div 2 ; 40 \div 20 ; 400 \div 200$.

The category 'Correct answers' was divided into two subcategories: 'Divisor is half of the dividend' and 'Even numbers'. In both of these subcategories, most of the pupils answered that there are an infinite number of solutions. In the subcategory 'Divisor is a half of the dividend', some fifth graders used the correct terms, some used a simple formulation, some wrote a quite complicated answer, and some had noticed a distinct kind of system.

- $\quad$ Because the dividend can be any number and the divisor is half of it.

- $\quad$ Because it can be divided by half of it.

- If you multiply some number by 2, the answer will be an even number;

this answer can then be divided with a number which is half of it, and the answer will be 2 .

- $\quad$ Because the dividend is increased by two and the divisor by one.

Like the third graders, many fifth-graders gave more or less the same reasons, even though they did not use infinity in their answer. A pupil who had given 'Hundreds' as the number of possible solutions, wrote

- $\quad$ Because you just divide it by half of it, e.g. $100 \div 50=2$.

Furthermore, in the subcategory 'Even numbers', there were simple and more complicated statements. We included in this subcategory the answers in which the respondents had also given examples as a justification.

- An even number is divided by half of it, and there are many even numbers.

- $\quad$ Because even numbers can be divided so that the answer is 2.

- $\quad$ All even numbers can be divided by two.

- $\quad$ Also, two million can be divided by one million and the answer is two.

The relation of the fluency (see Table 6) to other variables was studied. 
The fluency correlated with the first task in which pupils had to invent two calculations $(\mathrm{r}=0.24, \mathrm{~N}=356, \mathrm{p}=0.000)$, i.e. if pupils had calculated both tasks correct they had invented more new examples. The fluency correlated with the size of the numbers used in the calculations $(r=0.67, \mathrm{~N}=356, \mathrm{p}=0.000)$, i.e. if a pupil gave examples of divisions with two or more digit numbers they were more fluent. The fluency also correlated both with the conception about the amount of the numbers $(\mathrm{r}=0.33, \mathrm{~N}=356, \mathrm{p}=0.000)$ and with the justification $(\mathrm{r}=0.43, \mathrm{~N}=356, \mathrm{p}=0.000)$. In fact, the fluency correlated with all parts of the task, including with the first one unlike at the third grade. It seems that if a pupil had started to invent many examples of the division s/he was able to approach the idea of infinity of numbers. It is possible that the third grade pupils made more carelessness mistakes.

\section{Comparing the situation in the $3^{\text {rd }}$ and in the $5^{\text {th }}$ grades}

We wanted to determine if there had been some development in pupils' ability to solve a non-standard problem. In addition, we were interested in the possible development of pupils' idea of infinity.

The third-graders' two examples in the first part of the task were more frequently correct than the fifth-graders' examples in the corresponding task $(\mathrm{Z}=2.27, \mathrm{p}=0.05)$. The fifth graders' worse performance probably results from the frequency of the typical mistake of not understanding the meaning of the order of the numbers in division (e.g. Huhtala \& Laine, 2004). The fifth-graders left the second task (invent more examples) empty more frequently than the third-graders did $(Z=4.58, p=0.01)$. Third-graders are younger and, therefore, probably more conscientious and want to do their best, unlike fifth-graders at the beginning of puberty and tending to rebel against the rules. There were, however, no differences between the number of pupils who were fluent, i.e. gave more than six examples in this task. When looking more closely at the examples, it can be observed that the fifth-graders used larger numbers than the third-graders did in their calculations $(Z=4.60, p=0.001)$. Over $60 \%$ of the $5^{\text {th }}$ graders used numbers bigger than 20 in their divisions in comparison to $50 \%$ of the $3^{\text {rd }}$ graders.

In the task in which pupils were asked about the number of solutions, third graders' answers were more frequently coded as incorrect $(Z=5.29, \mathrm{p}=$ 0.001 ) because they gave more examples instead of answering the question. The third-graders' estimations about the number of solutions were also more frequently smaller than those the fifth-graders $(Z=2.99, p=0.01)$. Pupils' understanding of the concept of infinity did not, however, develop from the $3^{\text {rd }}$ to the $5^{\text {th }}$ grade; 32 pupils on third grade and 50 pupils on fifth grade were able both to 
use the concept of infinity and to give a correct justification. It is intriguing that only eleven of the pupils who had used the concept of infinity and given a correct justification in the $3^{\text {rd }}$ grade also did so in the $5^{\text {th }}$ grade. When comparing pupils' written explanations, we observed that the $5^{\text {th }}$ graders had given justifications more frequently: altogether, $51 \%$ of the $3^{\text {rd }}$ graders had no justification compared to $36 \%$ of the $5^{\text {th }}$ graders $(Z=4.06, p=0.001)$. The explanations were, however, not of better quality, because the biggest increase was in the explanations that showed that the pupils had no idea how to correctly answer the question. It seems that more pupils in the fifth grade had explained something in order not to leave the task empty, and that older pupils are usually more fluent in writing their ideas.

\section{Conclusions}

It is not possible to fully compare the results between the $3^{\text {rd }}$ and $5^{\text {th }}$ grades, because the tasks were different and division is a far more abstract concept than subtraction for the pupils. Although pupils should be familiar with the concept of potential infinity as early as at the $3^{\text {rd }}$ grade, it seems that this concept remains problematic at the $5^{\text {th }}$ grade (cf. Pehkonen \& Hannula, 2006). This is understandable because the concept of infinity is not a central topic in curriculum; therefore, there are no exercises in the textbooks concentrating in this concept, for example. That is why it depends on the teacher as to how much $\mathrm{s} /$ he uses time with this concept. It is also possible that this concept is not very clear for the teachers (cf. Hannula, Laine, Pehkonen, \& Kaasila, 2012).

It is essential to engage with the concept of infinity in the different fields of mathematics. Otherwise, pupils' only idea of infinity will be that of a neverending process (Monaghan, 2001), as was confirmed in our study. In addition, it is important to practice justifying solutions, as stated in the curriculum for the Finnish comprehensive school (NBE, 2004), because even at the fifth grade some of the pupils still had difficulties in explaining their thinking.

It was interesting to see how this guiding task composed of four parts functioned in this study. It seemed that if a pupil started to invent many examples, i.e. was fluent, s/he was able to come closer to the idea of infinity, and was therefore able to solve the problem. It is important in teaching to use open problems because they encourage pupils to invent different solutions. When pupils are used to inventing many solutions, it will probably also be easier for them to solve problems. It would be interesting in the next study to compare the results in experimental and control schools in order to determine the possible effect of the three-year intervention that was carried out in the experimental schools. 
It is also important to pay attention to pupils' explanations (Walshaw \& Anthony, 2008). For example, although some of the pupils were able to give infinity as an answer, they were not able to explain it, i.e. they did not fully understand their answer. In contrast, some of the fifth graders answered, for example, that there are fewer than 20 solutions to the division with the quotient of 2 but their explanation contained elements of understanding. Perhaps their understanding of numbers was restricted to small numbers. These pupils need a different kind of guidance from their teacher.

Ultimately, teachers should also pay careful attention to pupils' answers in written tests because in this way they will obtain useful information about the state of and possible problems in pupils' thinking. This helps the teachers to ask such pupils questions that in turn help pupils to deepen their understanding. Therefore, it is essential to create within the class a safe emotional atmosphere that promotes conversation and explanation.

\section{References}

Becker, J. P., \& Shimada, S. (1997). The Open-Ended Approach: A New Proposal for Teaching Mathematics. Reston (VA): NCTM.

Boaler, J. (1998). Open and closed mathematics: Student experiences and understandings. Journal for Research in Mathematics Education, 29(1), 41-62.

Ericsson, K. A. (2003). The Acquisition of Expert Performance as Problem Solving. In J. E. Davidson \& R. J. Sternberg (Eds.), The Psychology of Problem Solving (pp. 31-83). Cambridge: Cambridge University Press.

Guilford, J. P. (1956). The structure of intellect. Psychological Bulletin, 53(4), 267-293.

Hannula, M. S., Laine, A., Pehkonen, E., \& Kaasila, R. (2012). Learning density of numbers in elementary teacher education. In G. H. Gunnarsdottir, F. Hreinsdottir, G. Palsdottir, M. Hannula, M. Hannula-Sormunen, E. Jablonka, U. T. Jankvist, A. Ryve, P. Valero, \& K. Waege (Eds.), Proceedings of Norma 11: The Sixth Conference on Mathematics Education in Reykjavík, May 11.-14. 2011 (pp. 289297). Reykjavik: University of Iceland Press.

Huhtala, S., \& Laine, A. (2004). Mini-theories as part of pupils' views of mathematics - division as an example. In A. Engström (Ed.), Democracy and Participation. A Challenge for Special Needs Education in Mathematics: Reports from the Department of Education 7 (pp. 177-188). Örebro: University of Örebro. Kantowski, M. G. (1980). Some Thoughts on Teaching for Problem Solving. In S. Krulik \& R. E. Reys (Eds.), Problem Solving in School Mathematics: NCTM Yearbook 1980 (pp. 195-203). Reston (VA): Council.

Kwon, O. N., Park, J. H., \& Park, J. S. (2006). Cultivating divergent thinking in mathematics through an open-ended approach. Asia Pacific Education Review, 7(1), 51-61. 
NBE. (2004). National Core Curriculum for Basic Education 2004. Retrieved from http://www.oph.fi/ english/publications/2009/national_core_curricula_for basic education

Nohda, N. (2000). Teaching by Open-Approach Method in Japanese Mathematics Classroom. In T.

Nakahara \& M. Koyama (Eds.), Proceedings of the PME-24 Conference: Vol. 1 (pp. 39-53). Hiroshima:

Hiroshima University.

OECD. (2006). Assessing Scientific, Reading and Mathematical Literacy: A Framework for PISA 2006.

Paris: OECD.

Patton, M. (2002). Qualitative research and evaluation methods. Thousand Oaks: Sage.

Pehkonen, E. (2004). State-of-the-Art in Problem Solving: Focus on Open Problems. In H. Rehlich \& B. Zimmermann (Eds.), ProMath Jena 2003: Problem Solving in Mathematics Education (pp. 93-111).

Hildesheim: Verlag Franzbecker.

Pehkonen, E., \& Hannula, M. S. (2006). Infinity of numbers: a complex concept to be learnt? In S.

Alatorre, J. L. Cortina, M. Sáiz, \& A. Méndez (Eds.), Proceedings of PME-NA in Merida: Vol. 2 (pp. 152-154). Merida: Universidad Pedagógica Nacional.

Polya, G. (1945). How to Solve It? A New Aspect of Mathematical Method. Princeton, NJ: Princeton University Press.

Schoenfeld, A. H. (1985). Mathematical Problem Solving. Orlando (FL): Academic Press.

Shimada, S. (1997). The Significance of an Open-Ended Approach. In J. Becker \& L. Shimada (Eds.), The open-ended approach (pp. 1-9). Reston (VA): NCTM.

Silver, E. A. (1997). Fostering Creativity through Instruction Rich in Mathematical Problem Solving and Problem Posing. Zentralblatt für Didaktik der Mathematik, 29(3), 75-80.

Steinberg, R., Empson, S., \& Carpenter, T. (2004). Inquiry into children's mathematical thinking as a means to teacher change. Journal of Mathematics Teacher Education, 7, 237-267.

Torrance, E. P. (1974). Torrance Tests of Creative Thinking. Lexington (Mass.): Personnal Press/ Ginn and Company (Xerox Corporation).

Treffinger, T. J. (1995). Creative problem solving: Overview and educational implications. Educational Psychology Review, 7(3), 301-312.

Walshaw, M., \& Anthony, G. (2008). The Teacher's Role in Classroom Discourse: A Review of Recent Research Into Mathematics Classrooms. Review of Educational Research, 78(3), 516-551.

Wheeler, M. M. (1987). Children's understanding of zero and infinity. Arithmetic Teacher, 15(3), 42-44. 


\section{Biographical note}

ANu LAINe, Dr., is an adjunct professor in mathematics education, working as a university lecturer in the Department of Teacher Education at the University of Helsinki in Finland. Her research interests include affects, communication and problem solving in mathematics education.

LIISA NÄVERI, PhD, is working as a university lecturer in the Department of Teacher Education at the University of Helsinki in Finland. Her research interests include problem solving and understanding in mathematics learning.

Maija Aнtee, $\mathrm{PhD}$, is a professor (retired) in the field of mathematics and science education in the Department of Teacher Education at the University of Jyväskylä in Finland. Her research interest is more in physics education.

Erkki Pehkonen, Dr., is a full professor (retired) in the field of mathematics and informatics education in the Department of Teacher Education at the University of Helsinki in Finland. He is interested in problem solving with a focus on motivating middle grade pupils, as well as in understanding pupils' and teachers' beliefs and conceptions about mathematics teaching. 